\title{
Discrimination of Acne Vulgaris with Human Scalp Hair Tissues Using FTIR-ATR Spectroscopy
}

\author{
Padmavathi $\mathrm{R}^{1}$, Rajamannan $\mathrm{B}^{2}$ Gunasekaran $\mathrm{S}^{3}$, Ramkumar GR ${ }^{4}$, Sankari G ${ }^{5}$, Muthu $\mathrm{S}^{6}$ \\ 1 Department of Physics, Meenakshi Sundararajan Engineering College, Kodambakkam, Chennai, 600024, TN, India. \\ 2 Engineering physics, FEAT Annamalai University, Annamalai Nagar, 608002, Chidambaram, TN, India. \\ 3 Research and development St. Peter's institute of Higher Education and Research, St. Peter's University, Avadi, \\ Chennai, 600054, TN, India. \\ 4 Department of Physics, C. Kandaswaminaidu College for Men, Chennai-600102, India. \\ 5 Department of Physics, Meenakshi College for Women's, Kodambakkam, Chennai-600024, India. \\ 6 Department of Physics, Govt. Thirumagal Mills College, Gudiyatham-632602, Vellore, TN, India.
}

\section{Correspondence; pathmavati@gmail.com}

\begin{abstract}
Acne vulgaris is a chronic skin disease, which occurs due to inflammation of the hair follicles and sebum producing (sebaceous) glands of the skin called pilosebaceous unit and the anaerobic propionic acne bacterium, P. Acne. Human sebum is dominantly made up about $57.5 \%$ of triglycerides and fatty acids, $26 \%$ wax esters, $12 \%$ Squalene and $4.5 \%$ Cholesterol. The increased level Androgen hormone, sebum lipid composition, P. Acne overgrowth which induces monocytes and pro inflammatory cytokines attracts neutrophils, basophils, and $\mathrm{T}$ cells to the pilosebaceous unit and drive epithelial hyper proliferation i.e., Acne vulgaris. The actual Biomolecular changes due to acne vulgaris disease are present in the blood, in the sebum, and in the noninvasive sample of human scalp hair follicles. The main objectives of the present study are to analyze human scalp hair follicles samples using FTIR-ATR spectroscopy to compare and discriminate the spectral signatures of acne vulgaris and healthy scalp hair samples through acne biomarkers Protein, Amide I, Amide II and Squalene (LDL), using the method of internal ratio parameters.
\end{abstract}

Keywords: Acne Vulgaris, Hair tissue samples, Discrimination, FTIR-ATR.

\section{Introduction}

Acne is a multifactorial disease characterized by pathological alteration in pilosebaceous units of the neck and upper trunk. It results in the formation of comedones and inflammatory lesions such as papules, pustules, and nodules [1]. Acne is a chronic inflammatory skin disease and is occurs in adolescence [2]. The exact pathophysiology of acne remains unclear; the following are the four main interacting factors in the pathogenesis of acne vulgaris: viz., (i) The Keratinization, (ii) Excess sebum production, (iii) Colonization by P. acnes and (iv) Inflammation. The hair, sebum, and keratinocytes that fill the narrow follicle may produce a plug, an early sign of acne. The follicular plugging (comedones) prevents sebum from reaching the skin surface through a pore. The mixture of oil and dead skin cells provide a suitable environment for the gram-positive anaerobic bacterium ( $\mathrm{P}$ acnes) that normally live in the skin to grow in the plugged follicles [3]. The Propionic bacterium acnes play an important role in the initiation and prolongation of inflammation [4]. The P. acnes induces monocytes through the activation of toll-like receptor 2 (TLR-2) to secrete pro-inflammatory cytokines, such as tumor necrosis factor (TNF) and interleukin (IL)-1 $\beta$ and IL-8 [5, 6]. Among all cytokines that are released, a chemotactic factor IL8 is pivoted in attracting neutrophils, basophils, and $\mathrm{T}$ cells to the pilosebaceous unit, leading to the development of chronic inflammation [7] and accumulation of neutrophils at the site of acne 
comedones[8]. Due to phagocytosis, these accumulated neutrophils generate reactive oxygen and nitrogen species (ROS) and (RNS) respectively. ROS contains superoxide radicals (O2-), hydrogen peroxide $\left(\mathrm{H}_{2} \mathrm{O}_{2}\right)$, hydroxyl radical $(\mathrm{OH})$, singlet oxygen $\left({ }^{1} \mathrm{O}_{2}\right)$, peroxide radical $(\mathrm{LOO})$ ) and RNS contains nitric oxide (NO) and peroxynitrite (ONOO). These two ROS and RNS species cause inflammation and tissue injury.

Although acne pathology involves many factors, several studies indicate that oxidative stress caused by an imbalance between ROS and antioxidants in favor of ROS is one of the major factors [9-14]. Lipid peroxides, products of lipid peroxidation, may function as a cause of acne or as an acne generic agent or both. Oxidative stress causes damage to all cellular components through an attack on lipids, proteins, and DNAs. Due to an increase in free radicals, changes in the structure and functions of the proteins, lipids, and nucleic acids can lead to tissue damages. Based on this hypothesis, antioxidants that decrease oxidative stress and lipid peroxidation would be preventive and therapeutic agents against acne. The lipid damage hypothesis in the pathogenesis of acne was proposed half a century ago [15]. The biomarkers of oxidative stress are very important clinically and the evaluation of body tissue and fluids is used to diagnose pathological conditions, diseases. A component of sebum, particularly squalene is the main biomarker exhibit enhanced comedogenicity when oxidized. Squalene, which is specific to human sebum, protects the skin surface from lipid peroxidation. Both squalene and its oxidized products are at much higher levels in acne patients than in healthy individuals [16-19].

In recent days, for the treatment of acne vulgaris, many investigations are carried out. Among them, few recent treatments are given as follows. Herbs possessing antimicrobial and anti-inflammatory activity has been applied as a medical option for centuries. Lu-Je Chaudhary et al studied and examined, the suppressive effect of ethanolic oregano (Origanum Vulgare) extracts on live P. acnes- induced in vivo and in vitro inflammation [20]. Mohammed H.Talebe et al in 2018 in their studies, they assessed the healing and antimicrobial activity of the developed Nano emulsion of the most effective Essential oils (EO) in vivo in an acne mouse model as a potential new formulation for acne treatment [3]. Sanguisorba Officinalis L.Root (SOR) known to be effective against skin diseases, including urticarial, eczema, and allergic dermatologist [21] and against numerous bacteria [22-24]. Seongdae Kime et al in 2018 investigate anti-bacterial activity against p.acnes and the in vitro antioxidant activities of SOR. Shean-Chung Tang studied about the dual effects of Alpha-Hydroxy Acids (AHAs) on the skin. They review the various biological effects and mechanisms of AHAS on human keratinocytes and in an animal model [25]. The encapsulation of anti-acne drugs in various Nano technological carriers improve their efficacy and reduce side effects [26]. Agamia NF et al in 2018, investigate the effects of oral isotretinoin on the nucleocytoplasmic distribution of FoxO1 and FoxO3 proteins in sebaceous glands of patients with acne vulgaris [27].

In recent days, to diagnose diseases different methods have been used. Here is a non-invasive tissue that would enable clinicians to monitor diseases frequently, easily, and would have an impact on medical research and drug therapy. The main aim of this study is to discriminate the hair follicle tissue of acne vulgaris patients with healthy subjects as hair follicle undergoes biochemical changes due to acne vulgaris. The biomolecules present in the hair follicle is used as a probe in the investigation and its scrutiny using the FTIR-ATR molecular spectroscopic technique.

\section{Materials and Methods}


FTIR -ATR spectral measurements of human hair samples are carried out at Sophisticated Analytical Instrumentation Facility (SAIF-SPIHER), St. Peter's Institute of Higher Education and Research, Avadi, Chennai, India, using Perkin Elmer Spectrum-Two FTIR Spectrometer with Attenuated Total Reflectance accessory having highly reliable and single bounce diamond as its Internal Reflectance Element (IRE). Human scalp hair samples of healthy subjects and diseased persons, between the age group of 20-25 were procured from a leading laboratory with their consent. The single hair sample was plugged from the hair root (i.e., anagen phase, active growing stage of the hair fiber), collected in an airtight plastic cover, and stored at room temperature. The hair samples were soaked in acetone for 1 minute and soaked in distilled water later. To avoid noise signals occurring due to water content in the hair roots, the hair specimens are taken into laminar dry airflow to remove the water thoroughly. All the diseased and healthy hair samples were analyzed in the Mid IR region of 4000-450 cm-1. Since water is a good absorbent of IR radiation, it affects the actual spectral response of the test tissue and dominated in the FTIR spectrum of the hair tissue sample. After the removal of water content, the root of the hair sample was placed on the IRE crystal. Force is applied by the pressure gauge on the hair sample to prove good optical contact with the internal reflectance crystal. FTIR spectral measurements were recorded at room temperature and each sample, measurements were repeated to ensure the reproductively of the spectra. The spectra were baseline corrected and normalized at a particular vibrational band.

\section{FTIR-ATR spectral profile of human scalp hair tissue}

The FTIR-ATR absorption spectrum of healthy scalp hair is shown in Figure 1 and the vibrational band assignments of the biomolecules of the human hair fiber are shown in Table 1 Vibrational band assignment is done with the idea of the group frequencies of the various biomolecules present in the human scalp hair. The spectral region 3600-3000 cm-1 comprises of C-H, N-H, and OH stretching modes of Amide (A) [28]. Fort the methyl (CH3) group of proteins and lipids are asymmetric and symmetric modes were observed at $2962 \mathrm{~cm}-1$ and $2864 \mathrm{~cm}-1$ respectively, $\mathrm{CH} 2$ for the methylene group of Fatty acids, the asymmetric mode occurred at $2880 \mathrm{~cm}-1$ [29]. The strong absorption band at $1633 \mathrm{~cm}-1$ corresponds to $\mathrm{C}=\mathrm{O}$ stretching, vibration coupled with an in-plane bending of $\mathrm{N}-\mathrm{H}$ and $\mathrm{C}-\mathrm{N}$ is stretching modes (Amide I band) [30]. The vibration at $1516 \mathrm{~cm}-1$ due to $\mathrm{C}=\mathrm{O}$ stretching coupled with $\mathrm{C}-\mathrm{N}$ stretching and bending deformation of $\mathrm{N}-\mathrm{H}$ in the protein backbones [31]. The absorption in the keratin spectrum is attributed to the deformation and bending modes of the $\mathrm{C}-\mathrm{H} / \mathrm{CH} 2 / \mathrm{CH} 3$ groups originating from the various amino acid (SC) side chains [32]. The bands are exemplified as medium, broad absorption at $1454 \mathrm{~cm}-1$ (LDL), while the band at $1245 \mathrm{~cm}-1$ is due to asymmetric (PO2) stretching vibrations of Lipid phosphate of amino acid [33]. The Spectral band at $1068 \mathrm{~cm}^{-1}$ is due to the contribution of C-O stretching vibrations of glucose.

\section{Discrimination of Acne vulgaris Human Scalp Hair}

The present paper focuses mainly on qualitative and quantitative studies on healthy and acne vulgaris human scalp hair tissues using FTIR-ATR spectroscopy. FTIR absorption spectra of 20 healthy human scalp hair samples and 20 Acne human scalp hair samples were recorded. The spectral signatures of overlaid average spectra of healthy and acne vulgaris tissues are shown in Figure 2. Figure 2 emphasizes the difference in the intensity of IR absorption exhibited by the tissues, there is no spectral difference between the healthy and acne, hair tissue samples with respect to wave numbers of various vibrational modes, but a considerable difference in the intensity of IR absorption of some specific vibrational modes of biomolecules present. The squalene main biomarker for acne vulgaris has occurred at $1454 \mathrm{~cm}^{-1}$, whose absorption is high in acne patients when compared to healthy subjects. 
Ottaviani et al. 2010 the renowned researcher suggests the direct involvement of squalene peroxidation products on the onset of an inflammatory state in early acne lesions [34]. Hence, the abnormalities in lipid and protein metabolism in acne are higher in the above said, secretion of $\beta$ defensing and IL-8 protein and squalene (LDL) on target (i.e. Hair) tissues. Among the lipid alterations, high-density lipoprotein (HDL) levels, which significantly decrease in patients with lesions, and the difference in the height of the histogram is important in the discrimination of acne vulgaris tissues from healthy subjects to LDL (low-density lipoproteins) levels. Which increases as the acne condition becomes more severe [35]. Based on these, vibrational bands observed at $3264 \mathrm{~cm}-1$ (Protein), $1633 \mathrm{~cm}-1$ (Amide I), $1516 \mathrm{~cm}$-1 (Amide II), $1454 \mathrm{~cm}-1$ (Squalene- LDL) have been considered as biomarkers for diagnosis of acne vulgaris. In order to get exact deviations, and the intensity of absorption in the discrimination of acne vulgaris from healthy tissues, internal parameter ratios is calculated. This deals with the ratio of the intensity of infrared absorption of specific sensitive infrared bands. The sensitivity exhibited by the FTIR spectral bands of protein and lipid bands due to the IR absorption of acne vulgaris tissues clearly indicates that these are the key markers in the investigation of acne vulgaris.

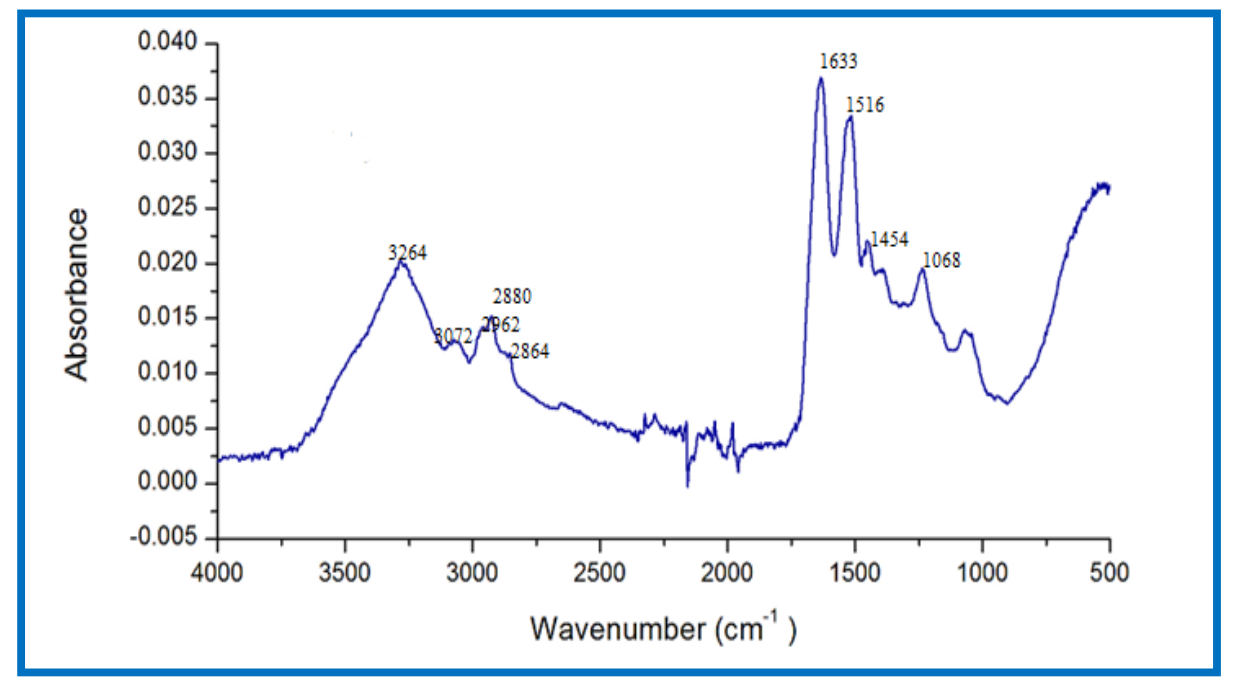

Figure 1 Average FTIR-ATR Spectrum of healthy Human Scalp Hair tissue

\section{Statistical Analysis}

Internal parameter ignores the difference in the amount of the sample under investigation, it nullifies the contradiction in the quantity of the sample and gives measured out exact deviation in the ratio of R1 (3264/2864), R2 (1633/2864), R3 (1516/2864) and R4 (1454/2864) of acne hair tissue. The absorption peaks of proteins and lipids in acne patients are more than a healthy person. The deviations in the internal ratio parameters of proteins and lipids in health and acne vulgaris tissues are provided clearly in Tables 2 . For a better understanding of deviation observed from internal ratio parameter calculations, the data obtained from internal ratio parameters are picturized-using histograms as shown in Figure 3. The histograms drawn between the ratios of Protein / Lipid, Amide I /Lipid, Amide II / Lipid, and Squalene / Lipid show the increase in height of the histogram of acne vulgaris.

Table 1 FTIR-ATR spectrum and vibrational analysis of biomolecules present in the human scalp Hair tissue 
5 of 11

\begin{tabular}{|c|c|}
\hline$\left(\mathrm{cm}^{-1}\right)$ & \\
\hline 3264 & N-H stretching mode (Amide A) of Protein \\
\hline 3072 & Amide $-\mathrm{B}$ band due to overtone of Amide I band \\
\hline 2962 & Asymmetric stretching vibrations of $\mathrm{CH}_{3}$ of proteins and Lipids \\
\hline 2880 & Asymmetric stretching vibrations of $\mathrm{CH}_{2}$ methylene group of fatty acids \\
\hline 2864 & $\mathrm{CH}_{3}$ symmetric stretching of methane groups of proteins and Lipids \\
\hline 1633 & $\mathrm{C}=\mathrm{O}$ symmetric stretching vibrations of amide group Amide I \\
\hline 1516 & $\begin{array}{l}\text { Amide II band due to N-H bending vibration strongly coupled C-N } \\
\text { stretching of Proteins }\end{array}$ \\
\hline 1454 & $\delta \mathrm{C}-\mathrm{H} / \mathrm{CH}_{2} / \mathrm{CH}_{3}$ of both lipid and protein groups (LDL), Squalene \\
\hline 1245 & $\begin{array}{l}\text { Asymmetric } \mathrm{P}=\mathrm{O} \text { stretching vibrations of } \mathrm{PO}_{2} \text { stretching of Lipid } \\
\text { Phosphate }\end{array}$ \\
\hline 1068 & C-O stretching vibrations of glucose region \\
\hline
\end{tabular}

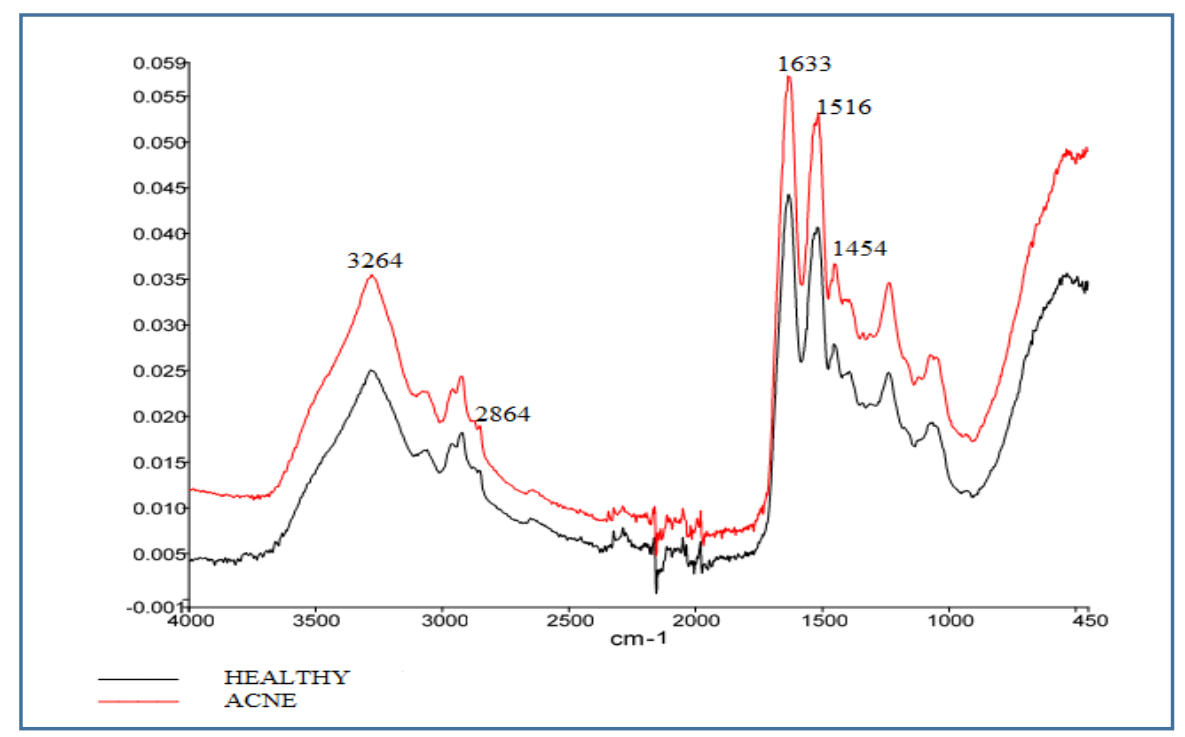

Figure 2 Overlaid Average FTIR-ATR Spectra of Healthy and Acne Vulgaris Human Scalp Hair tissues

The statistical test was carried out for these four intensity ratio parameters. The results are summarized in Tables 3 and pictorial representation with standard deviations is shown in Figure 4. It is noticed from Table 3 that the hair tissues of acne vulgaris patients had statistically significantly higher levels of protein and lipid content than the healthy persons. The mean intensity ratio of R1 levels is $2.0460 \pm 0.3584$ in acne patients and $1.6971 \pm 0.1485$ in healthy individuals. This shows the mean intensity ratio of protein and lipids in acne patients is very much greater than healthy individuals. The mean intensity ratio R2 level is 4.2167 (1.3056 in acne patients and 2.8878 (0.5313 in healthy individuals, thereby justifying the mean intensity ratio of Amide I and lipid for acne patients are very much greater than healthy individuals. The mean intensity ratio of R3 levels is $3.8105 \pm 1.2124$ in acne patients and $2.6356 \pm 0.4867$ in healthy individuals. This again confirms the mean intensity ratio of Amide II and lipids in acne patients is very much greater than healthy individuals. The mean intensity ratio of R4 levels is $2.6935 \pm 0.7971$ in acne 
patients and $1.7591 \pm 0.3603$ in healthy individuals. This gives strong support that the mean intensity ratio of Squalene and lipids in acne patients is very much greater than those of healthy individuals.

Table 2 Intensity ratio parameters of Healthy and Acne Vulgaris tissues of Protein / Lipid,

Amide I / Lipid, Amide II / Lipid and Squalene / Lipid

\begin{tabular}{|c|c|c|c|c|c|c|c|c|}
\hline \multirow{2}{*}{ Samples } & \multicolumn{2}{|c|}{ Protein / Lipid } & \multicolumn{2}{l|}{ Amide I / Lipid } & \multicolumn{2}{l|}{ Amide II / Lipid } & \multicolumn{2}{c|}{ Squalene / Lipid } \\
\cline { 2 - 9 } & \multicolumn{2}{|c|}{$\mathbf{I}_{3264 / 2864}$} & \multicolumn{2}{|c|}{$\mathbf{I}_{1633 / 2864}$} & \multicolumn{2}{|c|}{ I 1516/2864 } & \multicolumn{2}{|c|}{ I 1454/2864 } \\
\cline { 2 - 9 } & Healthy & $\begin{array}{c}\text { Acne } \\
\text { Vulgaris }\end{array}$ & Healthy & $\begin{array}{c}\text { Acne } \\
\text { Vulgaris }\end{array}$ & Healthy & $\begin{array}{c}\text { Acne } \\
\text { Vulgaris }\end{array}$ & Healthy & $\begin{array}{c}\text { Acne } \\
\text { Vulgaris }\end{array}$ \\
\hline 1 & 1.9606 & 2.8254 & 3.5906 & 7.2222 & 3.3307 & 6.6508 & 2.1969 & 4.3968 \\
\hline 2 & 1.7778 & 1.9606 & 2.963 & 3.6535 & 2.7099 & 3.3386 & 1.016 & 2.1732 \\
\hline 3 & 1.6233 & 2.9211 & 2.214 & 6.9605 & 2.0605 & 6.3158 & 1.4186 & 4.3026 \\
\hline 4 & 2.0000 & 2.0758 & 4.5606 & 4.2424 & 4.1364 & 3.7273 & 2.8485 & 2.6136 \\
\hline 5 & 1.7241 & 2.2661 & 3.1724 & 5.2110 & 2.8793 & 4.6881 & 1.9052 & 3.3028 \\
\hline 6 & 1.7711 & 2.2427 & 2.811 & 5.3786 & 2.607 & 4.8155 & 1.7662 & 3.2816 \\
\hline 7 & 1.6933 & 1.7591 & 2.6626 & 3.4234 & 2.4601 & 3.0949 & 1.6503 & 2.1825 \\
\hline 8 & 1.8571 & 2.0918 & 3.0357 & 5.2449 & 2.6929 & 4.7347 & 1.7786 & 3.2347 \\
\hline 9 & 1.5848 & 1.8293 & 2.2712 & 3.0732 & 1.9915 & 2.6768 & 1.3051 & 1.8293 \\
\hline 10 & 1.6418 & 1.7349 & 2.8806 & 2.9628 & 2.6119 & 2.7372 & 1.8060 & 1.7930 \\
\hline 11 & 1.5773 & 1.7667 & 2.493 & 2.9528 & 2.2448 & 2.7444 & 1.6399 & 1.7922 \\
\hline 12 & 1.7750 & 1.8122 & 2.975 & 2.9771 & 2.7875 & 2.7863 & 1.9000 & 1.9542 \\
\hline 13 & 1.3119 & 2.1529 & 2.1835 & 3.9529 & 2.0367 & 3.6000 & 1.5688 & 2.4118 \\
\hline 14 & 1.6310 & 1.7725 & 2.506 & 2.5059 & 2.2798 & 2.2797 & 1.5536 & 1.5536 \\
\hline 15 & 1.6418 & 1.7035 & 2.8806 & 3.6627 & 2.6119 & 2.7209 & 1.806 & 2.5930 \\
\hline 16 & 1.6340 & 1.6901 & 3.0825 & 3.7777 & 2.8041 & 3.4327 & 1.8763 & 2.6783 \\
\hline 17 & 1.7238 & 2.0000 & 3.1429 & 4.1066 & 2.8952 & 3.8361 & 1.9429 & 2.5000 \\
\hline 18 & 1.6995 & 2.0544 & 2.8653 & 3.9116 & 2.5959 & 3.4966 & 1.7668 & 3.2176 \\
\hline 19 & 1.7407 & 2.4944 & 2.9722 & 5.4607 & 2.7315 & 5.0899 & 1.7963 & 3.3371 \\
\hline 20 & 1.5734 & 1.7666 & 2.493 & 3.6527 & 2.2448 & 3.4444 & 1.6399 & 2.7222 \\
\hline
\end{tabular}

The independent sample $\mathrm{t}$-test table as shown in Table 4 provides the actual results from the independent t-test and Levene's test for the equality of the variances. This analysis revealed a significant difference between healthy subjects and acne patients. Several studies that were done in China and Brazil showed an association between lipid profile with acne vulgaris $[36,37]$. In the present study, since $\mathrm{p}=$ 0.000 , the null hypothesis that the mean ratio $(R 1, R 2, R 3, R 4)$ of acne and healthy subjects are the same.

Table 3 Group Statistics T-Test of Hair tissues of Healthy and Acne Vulgaris tissues of Protein / Lipid, Amide I / Lipid, Amide II / Lipid and Squalene / Lipid 
7 of 11

\begin{tabular}{|c|c|c|c|c|c|}
\hline & Group & $\mathbf{N}$ & Mean & $\begin{array}{c}\text { Std. } \\
\text { Deviation }\end{array}$ & Std. Error Mean \\
\hline Protein / Lipid & Acne Vulgaris & 20 & 2.0460 & 0.3584 & 0.0801 \\
\hline & Healthy & 20 & 1.6971 & 0.1485 & 0.0332 \\
\hline Amide I / Lipid & Acne Vulgaris & 20 & 4.2167 & 1.3056 & 0.2919 \\
\hline & Healthy & 20 & 2.8878 & 0.5313 & 0.1188 \\
\hline Amide II / Lipid & Acne Vulgaris & 20 & 3.8105 & 1.2124 & 0.2711 \\
\hline & Healthy & 20 & 2.6356 & 0.4868 & 0.1089 \\
\hline Squalene / Lipid & Acne Vulgaris & 20 & 2.6935 & 0.7971 & 0.1782 \\
\hline & Healthy & 20 & 1.7591 & 0.3603 & 0.0806 \\
\hline
\end{tabular}

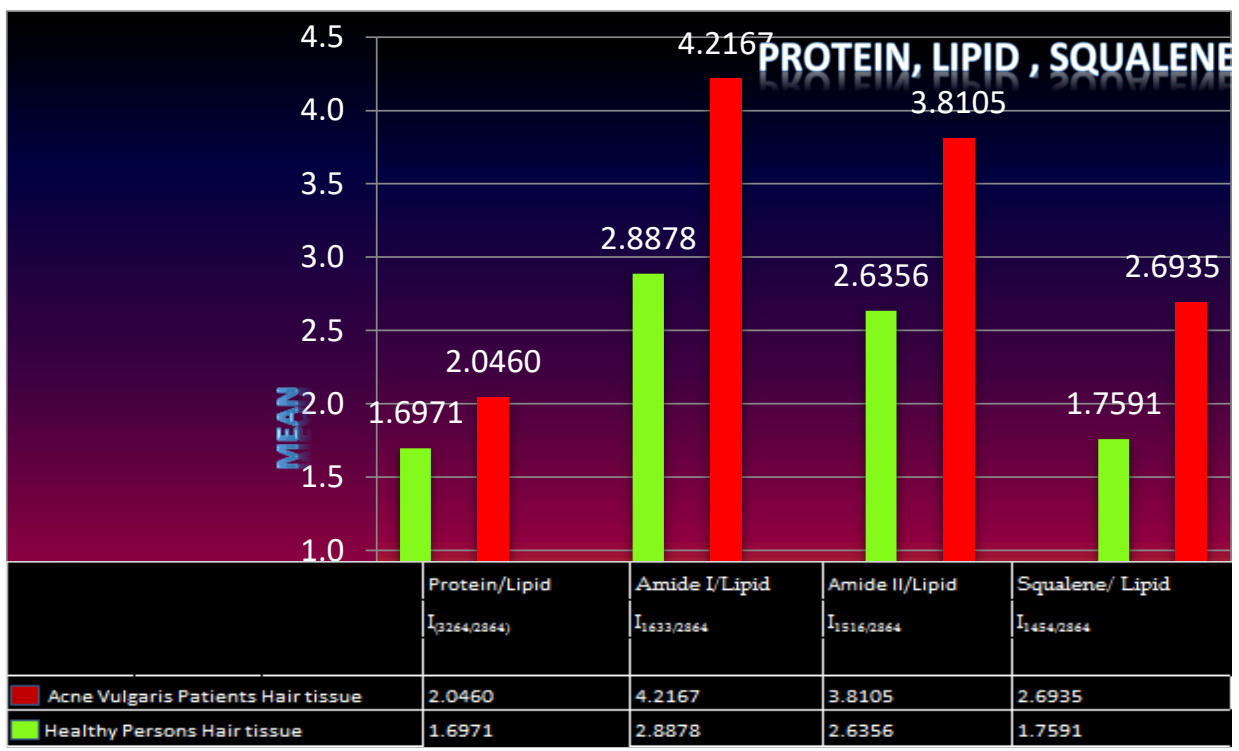

Figure 3 Histogram Indicating the Mean Intensity Ratios of Healthy and Acne Vulgaris Hair tissues of Protein / Lipid, Amide I / Lipid, Amide II / Lipid and Squalene / Lipid

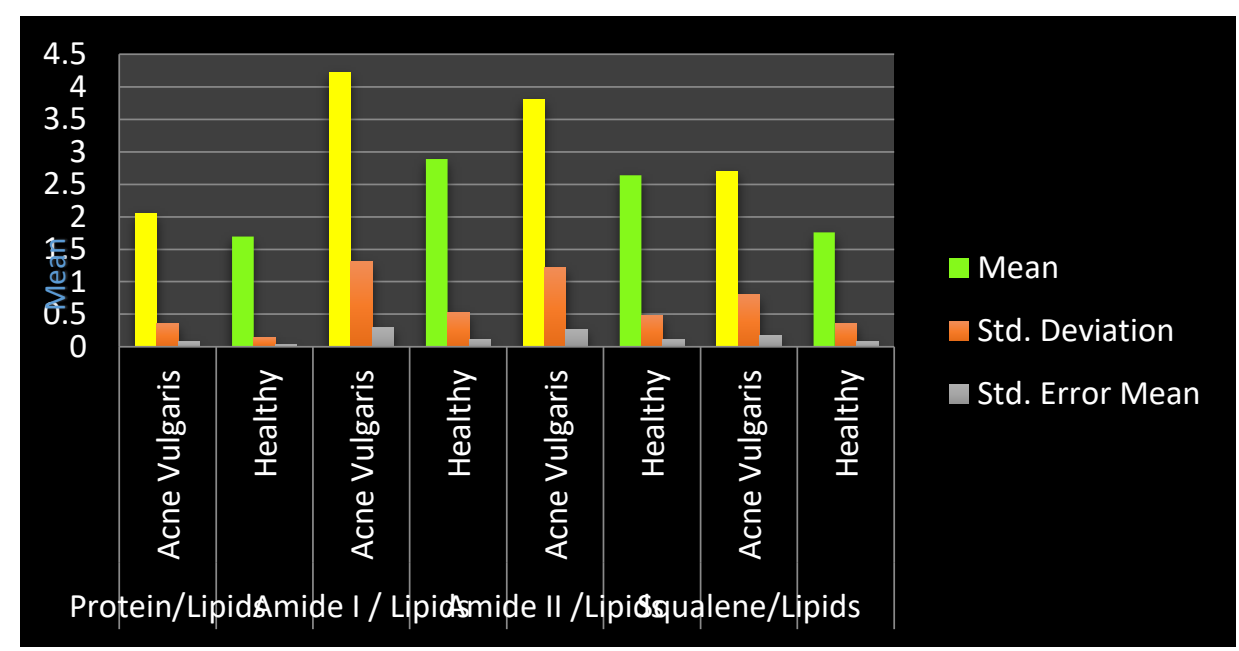

Figure 4 Group Statistics T-Test of Hair tissue of Healthy and Acne Vulgaris tissues of Protein / Lipid, Amide I / Lipid, Amide II / Lipid and Squalene / Lipid

Table 4 Independent Samples t-Test of Healthy and Acne Vulgaris Hair tissues of 
$\mathbf{R}_{1}=$ Protein $/$ Lipid, $\mathbf{R}_{2}=$ Amide $\mathbf{I} /$ Lipid, $\mathbf{R}_{3}=$ Amide II $/$ Lipid and $\mathbf{R}_{4}=$ Squalene $/$ Lipid

\begin{tabular}{|c|c|c|c|c|c|c|c|c|c|c|}
\hline \multirow{3}{*}{ 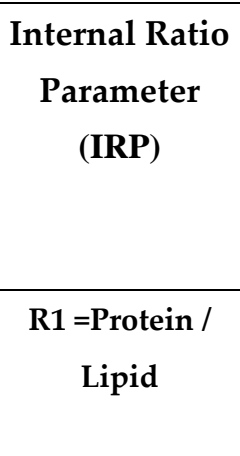 } & \multicolumn{3}{|c|}{$\begin{array}{c}\text { Levene's Test for Equality } \\
\text { of Variances }\end{array}$} & \multicolumn{7}{|c|}{ t-test for Equality of Means } \\
\hline & \multirow[b]{2}{*}{$\begin{array}{l}\text { Equal } \\
\text { variances } \\
\text { assumed }\end{array}$} & \multirow{2}{*}{$\begin{array}{c}\mathbf{F} \\
8.893\end{array}$} & \multirow{2}{*}{$\begin{array}{l}\text { Sig. } \\
0.005\end{array}$} & \multirow{2}{*}{$\begin{array}{c}\mathbf{t} \\
4.022\end{array}$} & \multirow{2}{*}{$\begin{array}{l}\mathbf{d f} \\
38\end{array}$} & \multirow{2}{*}{\begin{tabular}{|c|} 
Sig. \\
(2-tailed) \\
0.000 \\
\end{tabular}} & \multirow{2}{*}{\begin{tabular}{|c}
$\begin{array}{l}\text { Mean } \\
\text { Difference }\end{array}$ \\
0.3488
\end{tabular}} & \multirow{2}{*}{$\begin{array}{c}\begin{array}{c}\text { Std. } \\
\text { Error } \\
\text { Difference }\end{array} \\
0.0867\end{array}$} & \multicolumn{2}{|c|}{$\begin{array}{c}95 \% \text { Confidence } \\
\text { Interval of the } \\
\text { Difference }\end{array}$} \\
\hline & & & & & & & & & 0.1732 & 0.5244 \\
\hline & $\begin{array}{l}\text { Equal } \\
\text { variances } \\
\text { not } \\
\text { assumed }\end{array}$ & & & 4.022 & 25.33 & 0.000 & 0.3488 & 0.0867 & 0.1703 & 0.5274 \\
\hline \multirow[t]{2}{*}{$\begin{array}{c}\text { R2 = Amide I/ } \\
\text { Lipid }\end{array}$} & $\begin{array}{l}\text { Equal } \\
\text { variances } \\
\text { assumed }\end{array}$ & 10.637 & 0.002 & 4.684 & 38 & 0.000 & 1.4148 & 0.3021 & 0.8032 & 2.0263 \\
\hline & $\begin{array}{l}\text { Equal } \\
\text { variances } \\
\text { not } \\
\text { assumed }\end{array}$ & & & 4.684 & 25.72 & .000 & 1.4148 & 0.3021 & 0.7935 & 2.0360 \\
\hline \multirow[t]{2}{*}{$\begin{array}{c}\text { R3 = Amide II } / \\
\text { Lipid }\end{array}$} & $\begin{array}{l}\text { Equal } \\
\text { variances } \\
\text { assumed }\end{array}$ & 10.518 & .002 & 4.463 & 38 & .000 & 1.2532 & 0.2808 & 0.6847 & 1.8217 \\
\hline & $\begin{array}{l}\text { Equal } \\
\text { variances } \\
\text { not } \\
\text { assumed }\end{array}$ & & & 4.463 & 25.51 & .000 & 1.2532 & 0.2808 & 0.6755 & 1.8310 \\
\hline \multirow[t]{2}{*}{$\begin{array}{c}\text { R4=Squalene } / \\
\text { Lipid }\end{array}$} & $\begin{array}{l}\text { Equal } \\
\text { variances } \\
\text { assumed }\end{array}$ & 9.204 & .004 & 5.288 & 38 & .000 & 0.9856 & 0.1863 & 0.6083 & 1.36290 \\
\hline & $\begin{array}{l}\text { Equal } \\
\text { variances } \\
\text { not } \\
\text { assumed }\end{array}$ & & & 5.288 & 27.29 & .000 & 0.9856 & 0.1864 & 0.6033 & 1.3678 \\
\hline
\end{tabular}

The intensity ratio parameters of R1, R2, R3 and R4 for acne vulgaris patient's hair tissues were statistically higher than the healthy subjects. The Levene's test for the equality of variances helps in cheking whether the two variables have similar variances. According to this test, if the variances are equal, then the "Sig" will be greater than 0.05 . However, if the "Sig" value is less than 0.05 , the variance is unequal. In the present study, the results showed the value of "Sig" was less than 0.05; for the ratios of (R1, R2, R3, R4), thus the variance was found to be different in healthy subjects and acne patients. 
The pathogenesis of acne vulgaris is not completely clear for the past several decades and various studies have indicated that patients with acne suffered due to lipid peroxidation in particular acne growth, Several studies indicate that mainly oxidative stress is the main culprit which initiated inflammation in the pilosebaceous unit, creating a suitable environment for the P.acnes by the oxidation ofsebum is the initial step in the pathogenic process of acne. Hence, in this investigation, the normal human scalp hair sample was analyzed using FTIR-ATR spectrum and they were compared with spectral signatures of diseased acne samples and revealed major differences in absorption levels of metabolic components, viz., Protein, Amide I, Amide II and Squalene (LDL) i.e., R1 = I (3264 / 2864) (Protein / Lipid), R2 =I (1633 / 2864) (Amide I / Lipid), R3 =I (1516 / 2864) (Amide II / Lipid) and R4 =I (1454 / 2864) (Squalene / Lipid). From the internal ratio parameters results, it is clear that the acne patients have a high level of Protein and Lipid Squalene when compared with the healthy ones. Thus, FTIR-ATR spectroscopic technique shows very good results in detecting quantity variation in the functional groups present in the tissue components such as lipids and proteins. The results were compared with the group statistical data, which are exactly similar to the mean values of internal parameter ratios. Observed results are analyzed using an independent samples t-test, where the p-value $\mathrm{p}=0.000$ and "Sig" was less than 0.05 ; for the ratios of (R1, R2, R3, R4) where the variances are unequal, and value of 'Sig' (2), observed to be 0.005 , $0.002,0.002$ and 0.004 , it shows that the two independent variables were highly significant at $1 \%$ level. Thus, the variance was found to be different in healthy subjects and acne patients, which indicated that the spectral variations have provided significant differences in the healthy and acne vulgaris subjects.

\section{Acknowledgments}

The authors are thankful for the generous support rendered by Sophisticated Analytical Instrumentation Facility (SAIF-SPIHER), St. Peter's Institute of Higher Education and Research, Avadi, Chennai- 600054, for giving permission to deploy the advanced instrumentation FTIR-ATR spectrophotometer.

\section{REFERENCES}

1. Williams, H.C.; Dellavalle, R.P.; Garner, S. Acne vulgaris. Lancet 2012, 379, 361-372.

2. Bergfeld, W.F.; The pathophysiology of acne vulgaris in children and adolescents, Part 1.

Cutis. 2004; 74,92-97.

3. Mohammed, H. Taleb.; Nourtan F. Abdeitawab.; Rehab N. Shamma.; Sherein S, Abdelgayed.; Sarah S.Mohamed A.Farag and Mohammed A. Ramadan.; Origanum vulgare L. Essential Oil as a Potential Anti-Acne Topical Nanoemulsion-In Vitro and in Vivo Study, Molecules. 2018, $23,2164$.

4. Omer, H.; McDowell, A.; Alexeyev, O.A.; Understanding the role of Propionibacterium acnes in acne vulgaris: The critical importance of skin sampling methodologies. Clin. Dermatol. 2017, 35, 118-129. [CrossRef] [PubMed].

5. Kim,J.; Ochoa, M.T.; Krutzik, S.R.; Takeuchi, O.; Uemats, S.; Legaspi, A.J.; Brightbill, H.D.; Holland, D.' Cunliffe, W.J.; Akira $S$ et al. Activation of toll-like receptor 2 in acne triggers inflammatory Cytokine responses. J.Immunol. 2002, 169, 1535-1541. [CrossRef] [PubMed].

6. Kim, J. Review of the innate immune response in acne vulgaris: Activation of Toll-like receptor 2 in 
Acne triggers inflammatory cytokine responses. Dermatology. 2005, 211, 193-198. [CrossRef] [PubMed].

7. Brennan K, Zheng J, Interleukin 8. In xPharm: The Comprehensive Pharmacology Reference; Elsevier Inc.: New York, NY, USA, 2011; 1-4.

8. Akamatsu H, Horio T, Hattori K (2003) Increased hydrogen peroxide generation by neutrophils from patients with acne inflammation. Int J Dermatol, 2003; 42: 366-369.

9. Al-Shobaili, H.A .Oxidants and anti-oxidants status in acne vulgaris patients with varying severity, Ann Clin Lab Sci. 2014, 44, 202-207.

10. Bowe,W.P.; Patel. N.; Loan, A.C. Acne vulgaris: the role of oxidative stress and the potential Therapeutic value of local and systemic antioxidants. Drugs Dermatol. 2012, 11, 742-746.

11. Sahib, A.S.; Al-anbari, H.H.; Abu Raghil, A.R.; Oxidative stress in acne vulgaris: an important Therapeutic target. J MolPathophysiol, 2013,2, 27-31.

12. Arican, O.; Kurutas,E.B.; Sasmaz, S. Oxidative stress in patients with acne vulgaris. Mediators Inflamm. 2005, 380-384.

13. Sarici, G.; Cinar, S.; Armutcu. F.; Altinyazar, C.; Koca, R. et al. Oxidative stress in acne vulgaris. J EurAcad DermatolVenereol. 2010, 24, 763-767.

14. Al-Shobaili, H.A.; Alzolibani, A.A.; AI Robaee, A.A.; Meki, A.R.; Rasheed, Z.; Biochemical markers of oxidative and nitrosative stress in acne vulgaris: correlation with disease activity. J Clin Lab Anal, 2013, 27, 45-52.

15. Lorincz,A.l . Human skin lipids and their relation to skin diseases. Armed Services Technical Information Report, 1965, AD467008: 1-2.

16. Saint-Lager, D.; Baque, A.; Cohen, E.; Chivot, M.; A possible role for squalene in the pathogenesis of acne.I. In vitro study of squalene oxidation. Br J Dematol, 1986, 114, 535-542.

17. Hanaoka, H.; Ohkido, A.; Hattori, Y.; Maruta, T.; Arai T (1971) Reexamination of the sebaceous Function with relation tosequalene. Japanese J Dermatol. 1971, 81, 103.

18. Cotterill, J.A.; Cunliffe, W.J.; Williamson, B.; Bulusu, L. Further observations on the pathogenesis of acne. Br Med J,1972,3, 444-446.

19. Saint-Lager, D.;Baque, A.; Lefebvre, E.; Cohen,E.; Chivot, M. A. possible role for squalene in the pathogenesis of acne. II in vivo study of squalene oxides in skin surface and intra-comedonal lipids patients. Br J Dermatol .1986, 114, 543-552.

20. Lu-Je chauary , Tsung-Hsien Tsai, Tsung-Jung Lien, Wen-Cheng Huang, Jun-Jen Liu, Hsiang Chang, Mei-Ling Chang and Po-Jung Tsai, Ethanolic Extract of Origanum vulgare Suppresses Propionibacterium acnes-Induced Inflammatory Responses in Human Monocyte and Mouse Ear Edema Models, Moleculaes.2018, 23,1987.

21. Kim,S.H .; Kim,D.K.; Eom,D.O.; Kim,S.Y.; Kim,S.H.; Shin,T.Y.; Sanguisorba officinalis inhibits immediate-type allergic reactions. Nat. Prod.Sci. 2002, 8,177-182.

22. Shan,B.; Cai Y.Z.; Brooks,J.D.; Corke, H. The in vitro antibacterial activity of dietary spice and medicinal herb extras. Int.J.Food Microbiol. 2007,117,112-119.

23. Gawron-Gzella, A.; Witkowska-Banaszczak, E.; Bylka, W .; Dudek-Makunch, M.; Odwrot, A,Skrodzka, N.; Chemical composition, antioxidant and antimicrobial activities of sanguisorba officinalis L. extracta. Pharm.Chem.J. 2016, 50, 244-249.

24. Ginovyan, M.; Petrosyan, M.; Trchounian, A.; Antimicrobial activity of some plantmaterials 
used in Armenian traditional medicine. BMC complement. Altern.Med.2017, 17,50.

25. Shean-Chung Tang and Jen-Hung Yang. Dual effects of Alpha-Hydroxy Acids on the Skin ,Molecules. 2018, 23, 23-863.

26. Verma, S.; Utreja , P.; Kumar, L.; Nanotechnological carriers for treatment of acne, Recent Pat Antiinfect Drug Discov; 2018 Sep, Epub Ahead of print.

27. Agamia, N.F.; Hussein, O.M. Effect of oral isotretinoin on the nucleo-cytoplasmic distribution of FoxO1 and FoxO3 proteins in sebaceous glands of patietns with acne vulgaris, Abdelmaksksoud, RE et al, Exp Dermatol.2018 Sep 21.

28. Sankari, G.; Krishnamoorthy, E.; Jayakumaran, S.; Gunasekaran, S.; VishnuPriya, V.; Shyama, Subramaniam, S.; Surapaneni Krishna Mohan, Analysis of serum immunoglobulins using Fourier transform infrared spectral measurements, J. Biology and Medicine. 2010, 2, 42-48.

29. Akhtar, W.; Edwards HGM, Farwell DW, Nutbrown, M.; Fourier -Transform Raman apectroscopic study of human hair, Spectroshimica Acta Part A. 1997, 53 ,1021-1031.

30. Tu AT, Raman spectroscopy in Bioloy: Principles and applications, John wiley and Sons 1982.

31. Chen, Y.J.; Cheng, Y.D.; Liu, H.Y.; Lin, P.Y.; Wang, C.S.; Observation of biochemical imaging changes in human pancreatic cancer tissue using Fourier-transform infrared microspectroscopy, Chang Gung, Med J. 2006, 29, 518-27.

32. Barton ,P.A, Forensic Taponomy Investigation of Single $\alpha$-Keratin FibresUnder Environmental Stress Using A Novel Application of Ftir-Atr Spectroscopy of Chemetrics, Honours Thesis, Queensland University of Technology 2004.

33. Bantignies, L.; Fushs, G.; Carr, G .L.; Williams, G .P.; Lutz, D.; Marull, S.. Organic Reagent Interaction With Hair Spatially Characterized By Infrared Microspectroscopy, Using Synchrotron Radiation, Int Cosmet Sci. 1998, 20, (38), 94.

34. Ottaviani, M.; Emanuela Camera, and Mauro Picardo. Lipid Mediators in Acne, Mediators of Inflammation. 2010, 858176-6

35. Cunha ,M.G; Batista, A,L.; Macedo, M.S.; Filho, C.; Fonseca, F. Study of Lipid Profile in Adult Women with Acne. Clin Cosmet Investig Dermatol. 2015, 8 , 449-54.

36. Jiang, H.; Li, C.Y.; Zhou, L.; Lu, B.; Lin, Y.; Huang, X. et al. Acne Patients Frequently Associated with Abnormal Plasma Lipid Profile. J Dermatol. 2015; 42(3): 296-9.

37. Arora,M.K.; Seth, S.; Dayal, S.; Trehan, A.S.; Seth, M. Serum Lipid Profile in Female Patients with severe Acne Vulgaris. Clin Lb. 2014, 60, (7),1201-5. 